\title{
SPATIAL DYNAMICS OF ATLANTIC FOREST FRAGMENTS IN A RIVER BASIN
}

\author{
Elfany Reis do Nascimento Lopes ${ }^{1 *}$, Jocy Ana Paixão de Sousa ${ }^{2}$, José Carlos de Souza ${ }^{3}$, José Luiz Albuquerque \\ Filho $^{4}$, Roberto Wagner Lourenço ${ }^{5}$ \\ ${ }^{1 *}$ Federal University of the South of Bahia. Environmental Science Formation Center, Porto Seguro, Brazil. Science Enviromental \\ Postgraduate Degree, elfany@ufsb.edu.br \\ ${ }^{2}$ Sorocaba São Paulo State University (UNESP), Institute of Science and Technology, Sorocaba. Geoprocessing and Environmental \\ Mathematical Modeling Laboratory. Sorocaba, São Paulo, Brazil - jocy.sousa@ unesp.br \\ ${ }^{3}$ State Goiás University. Anapólis, Goiás, Brazil - jose.souza@ueg.com.br \\ ${ }^{4}$ Technological Research Institute of São Paulo (IPT). São Paulo, São Paulo, Brazil - albuzelu@ipt.br \\ ${ }^{5}$ Sorocaba São Paulo State University (UNESP), Institute of Science and Technology, Sorocaba. Geoprocessing and Environmental \\ Mathematical Modeling Laboratory - roberto.lourenco@unesp.br
}

Received for publication: 17/08/2018 - Accepted for publication: 01/07/2019

\begin{abstract}
Resumo
Dinâmica Espacial de Fragmentos Florestais de Mata Atlântica em Bacia Hidrográfica. Considerando a intrínseca relação entre vegetação e conservação dos recursos hídricos, objetivou-se avaliar a vegetação natural de mata atlântica através de métricas da paisagem e índices espectrais de vegetação, indicando caminhos para a sua conservação na bacia hidrográfica do rio Una, Ibiúna, São Paulo. Processou-se a partir dos vetores dos fragmentos florestais da bacia, a análise das métricas de paisagem e a extração de valores da média de altitude, declividade e distância da rede de drenagem para cada fragmento utilizando o ArcGis 10.3. Aplicou-se os índices de vegetação por diferença normalizada, de produção fotoquímica e fluxo de carbono através da combinação de bandas espectrais do vermelho, verde, azul e infravermelho próximo da imagem satélite RapidEye. Os resultados mostraram 197 fragmentos com tamanhos que variam entre 1 a 306 hectares e com formas irregulares. Os fragmentos maiores encontram-se em número reduzido, mas correspondem a $52 \%$ da área de cobertura vegetal da bacia. A vegetação apresentou níveis elevados de biomassa, mas uma produção fotossintética moderada, coincidindo para um fluxo de carbono também moderado. Identificou-se que os melhores escores estavam relacionados a fragmentos em altitudes mais elevadas, declivosas e com proximidade da drenagem. As ações para conservar os fragmentos de maiores áreas e traçar medidas de conscientização ambiental devem ser estimuladas, considerando que a alta vocação agrícola pode incitar a sua redução para o aumento da produção econômica.

Palavras-chave: Fragmentação. Recursos hídricos. Índices de vegetação. Floresta atlântica.
\end{abstract}

\begin{abstract}
Considering the intrinsic relationship between vegetation and conservation of water resources, we evaluated the natural vegetation of an Atlantic Forest fragment through landscape metrics and spectral vegetation indices, indicating ways for its conservation in the Una river basin, Ibiúna, São Paulo, Brazil. We analyzed landscape metrics and the extraction of mean altitude, slope, and distance from the drainage network for each fragment based on the vectors of forest fragments in the river basin, using ArcGis 10.3. Normalized difference vegetation indices, photochemical production, and carbon flux were estimated by combining red, green, blue, and infrared spectral bands near the RapidEye satellite image. The results showed 197 fragments with sizes ranging from 1 to 306 hectares and irregularly shaped. The largest fragments are few in number, but account for $52 \%$ of the river basin's vegetation cover area. The vegetation presented high levels of biomass but moderate photosynthetic production, coinciding for a moderate carbon flux. The best scores were related to fragments at higher altitudes, in sloping areas next to drainage sites. Actions to conserve the fragments of larger areas and draw up environmental awareness measures should be encouraged, since high agricultural vocation may incite the reduction of these areas to increase economic production.
\end{abstract}

Keywords: Fragmentation. Water resources. Vegetation indices. Atlantic Forest.

\section{INTRODUCTION}

The growth of productive and urban areas, in addition to temperature fluctuations, water stress periods, and the overexploitation of natural resources have highlighted the severity of the potential decline of vegetation, while attention is drawn to the need to conserve it. (CHOAT et al., 2012). Conservation studies have confirmed

FLORESTA, Curitiba, PR, v. 50, n. 1, p. 1053 - 1062, jan/mar 2020.

Lopes, E. R. N. et.al.

ISSN eletrônico 1982-4688 
the impact of changing vegetation cover on regional flora; physicochemical and environmental processes; and quality of life of populations, reinforcing the need for studies that indicate scenarios for conservation and change in the occupation of these areas. (LOURENÇO et al., 2014; KENNEL et al., 2015).

As river basins are considered both as basic planning units for environmental conservation and as systems where environmental and social elements are integrated, vegetated areas are highlighted in the study of these sites, especially in landscape behavior. In this context, vegetation has proved to be a fundamental aspect for the conservation of water areas, as it acts in the redistribution of rain, recharge of aquifers, formation of new humid atmospheric masses through interception by the forest canopy, percolation and storage of water in the soil, besides reducing erosion and attenuating flow rates and the effects of river eutrophication (TUNDISI, 2006; ÁVILA et al., 2014).

There is also the need for research in the Atlantic Forest domain, considered a biodiversity hotspot, that is, a priority area for conservation and that is severely threatened by the high degree of anthropic intervention. This biome is under increasing exploitation, with a deforestation rate of 18.267 hectares in the last two years. Only $12 \%$ of its original area is intact, thus placing it as one of the 22 threatened biomes in the world. (RIBEIRO et al., 2009; LOURENÇO et al., 2014; MCT, 2015).

Forest loss rates worldwide are alarming. In the United Kingdom, the forest area has decreased from $75 \%$ to $13 \%$, while England has only $10 \%$ of forests on its territory (FORESTRY COMMISSION, 2012). In Brazil, São Paulo State has a total area of 2.378,985 hectares of Atlantic forest, scattered in conservation units and in small fragments surrounded by agricultural and urban areas. (LOURENÇO et al., 2014; MCT, 2015).

The use of Geographic Information System (GIS) and Remote Sensing (RS) has helped the development of research focusing on the Atlantic Forest and enabled the use of techniques to evaluate plant traits in different territories. Geographic Information System allows the construction of a file management environment, while Remote Sensing allows vegetation monitoring based on photosynthetic specificities (AHAMED et al., 2011; JAMALI et al., 2014).

These spatial tools have combined the study of the Atlantic Forest area with its importance for river basin conservation. Other studies have investigated the effect of socioeconomic development on vegetation and defined environmental fragmentation rates over time. Moreover, the association between water body conservation and rainfall changes has also been studied in forested river basins.

From these contributions, studies on forest ecosystems become relevant in the context of environmental management and monitoring. They are extremely necessary in the case of water areas inserted in the Atlantic Forest biome, since vegetation is closely related to their conservation and studies have revealed potential degradation and incipient conservation actions (PIROVANI et al., 2014; JESUS et al., 2015).

The present study evaluates the spatial dynamics of the physical and spectral characteristics of Atlantic Forest fragments through landscape metrics, vegetation vigor indices, photosynthetic efficiency, and carbon flux, further indicating ways for the conservation of Atlantic Forest fragments in the Una river river basin, Ibiúna, São Paulo, Brazil.

The choice for the river basin lies in its understanding as a basic planning unit for environmental conservation and as a system where environmental elements are integrated, with unchanging physical limits. The vegetated areas are a highlight in these places that are in transition between urban and rural settings. In addition, the studied site has relevant water importance, providing the knowledge of the spatial behavior of vegetation.

\section{MATERIALS AND METHODS}

\section{Study area}

The study was conducted in the Una river basin, located entirely in Ibiúna city and belonging to the Tenth Water Resources Management Unit of Sorocaba and Middle Tietê (UGHRI 10), in the southeastern region of São Paulo State (Figure 1). 


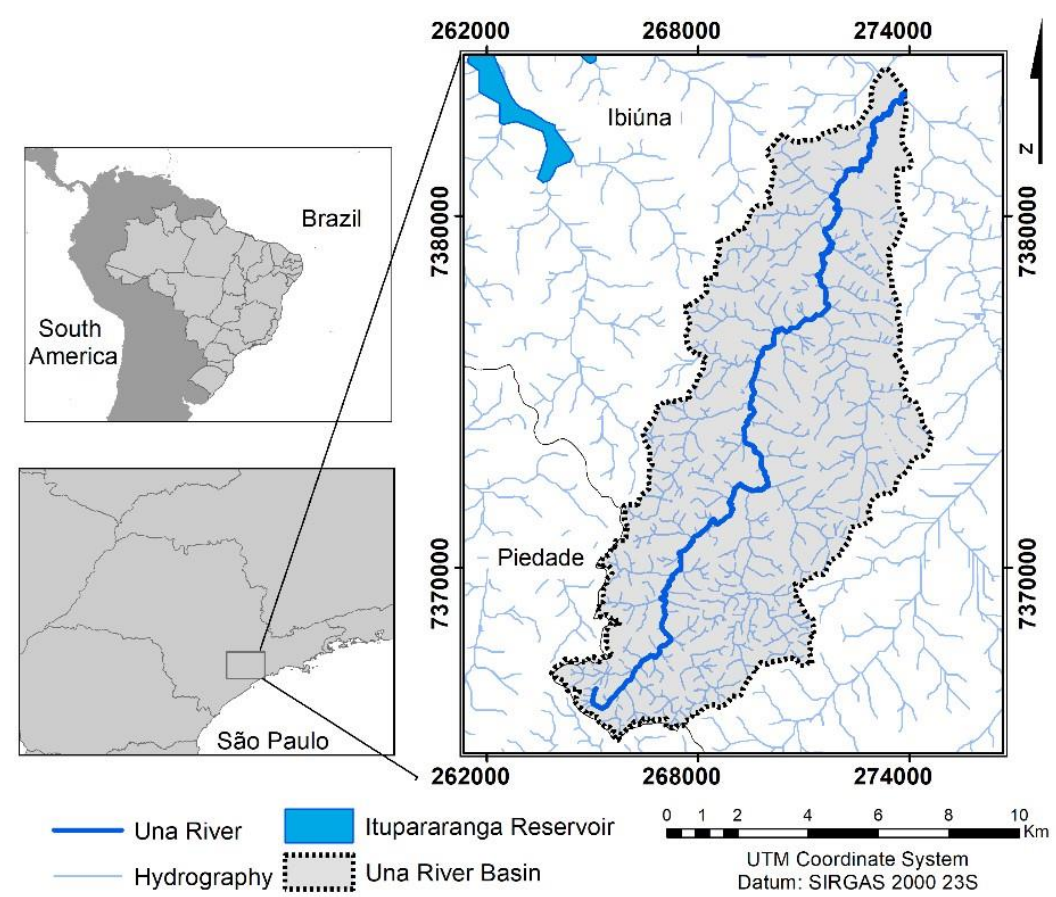

Figure 1. Location of the Una river basin, Ibiúna, São Paulo.

Figura 1. Localização da Bacia Hidrográfica do rio Una, Ibiúna, São Paulo.

The territorial extension of the river basin is $96 \mathrm{~km}^{2}$, having the Una river as the main course $(25 \mathrm{~km}$ long), receiving waters from the Cupim stream, Leopoldo stream, and Salto stream, and flowing into the main tributary (Sorocabuçu river) for the formation of the Itupararanga reservoir.

The climate of the river basin is defined as Cwa and the historical series from 1984 to 2014 defines the wet period from October to March, with the highest monthly average rainfall ( $242 \mathrm{~mm}$ ) being recorded for January. The dry period is defined between April to September, with August being the month with the lowest rainfall (34 $\mathrm{mm}$ ) (CIIAGRO, 2015). Furthermore, the river basin is inserted in the Atlantic Forest biome, with its head near the Environmental Protection Areas (EPAs) of Serra do Mar, Corumbataí, Botucatu, and Tejupá, and its mouth corresponding to the reservoir and EPA of Itupararanga.

The river basin has a transition zone between rural and urban areas, with a history of landscape fragmentation and sites used for intensive agriculture and urbanization, reinforcing the justification for a detailed investigation of the prospects of future scenarios for vegetation conservation.

\section{Mapping of forest fragments}

For the analysis of the metrics and spectral evaluation of fragments, we selected the vectors corresponding to Atlantic Forest fragments, mapped concurrently with the land use mapping. Considering the activity density in the river basin, all vectors of fragments equal to or larger than 1 hectare were selected to compose the study. Size classification was performed according to Pirovani et al. (2014), considering small fragments $(<5$ ha), medium fragments ( 5 - $50 \mathrm{ha})$, and large fragments (> $50 \mathrm{ha})$.

\section{Evaluation of forest fragment metrics}

The metrics of each fragment were calculated using the V-LATE extension in association with ArcGis 10.3 software and Microsoft Excel 2010. For analysis, fragment metrics were selected, as shown in Table 1. 
Table 1. Landscape metrics for forests fragments

Tabela 1. Métricas da paisagem para os fragmentos florestais

\begin{tabular}{c|l|c|c|c}
\hline \multicolumn{1}{c|}{ Level } & \multicolumn{1}{|c|}{ Metrics } & Acronyms & Unit & Value \\
\hline \multirow{5}{*}{ Class } & Class area & CA & ha & {$[0-\infty[$} \\
\cline { 2 - 5 } & Number of fragments per class & NP & adm. & {$[0-\infty[$} \\
\cline { 2 - 5 } & Edge density & ED & $\mathrm{m} / \mathrm{ha}$ & {$[0-\infty[$} \\
\cline { 2 - 5 } & Total edges & TE & $\mathrm{m}$ & \\
\cline { 2 - 5 } & Average spot size & MPS & ha & {$[0-$ CA [} \\
\cline { 2 - 5 } & Average fragment edges & SHAPE & adm. & {$[1-\infty[$} \\
\cline { 2 - 5 } & Shape index & AREA & ha & {$[0-\infty[$} \\
\hline \multirow{5}{*}{ Fragment } & Area & PERIM & $\mathrm{m}$ & {$[0-\infty[$} \\
\cline { 2 - 5 } & Perimeter & PARA & adm. & {$[0-\infty[$} \\
\cline { 2 - 5 } & Perimeter/Area ratio & FRAC_DIM & & \\
\cline { 2 - 5 } & Fractal dimension & & \\
\hline
\end{tabular}

Source: Adapted from McGarigal (2015).

Fonte: Adaptado de McGarigal (2015).

\section{Forest fragment assessment and physical characteristics of the river basin} de drenagem.

Os fragmentos foram correlacionados com as características de altitude, declividade e distância da rede The fragments were correlated with the following characteristics: altitude, slope, and distance from the drainage network.

River Basin altimetry was generated according to the construction of the Digital Terrain Model (DTM), derived from the contour lines and quoted points extracted by vectorization of the topographic map of Ibiúna city and subjected to the generation of the Triangulated Irregular Network (TIN) and its conversion into a matrix file. The slope was generated according to DTM processing in the Slope command, being subsequently categorized into slope percentage classes according to morphological classification as flat, gently undulating, undulating, strongly undulating, mountainous, and steep relief (EMBRAPA, 2006).

The averages of the values corresponding to the altitude and slope for each forest fragment were extracted with the Zonal Statistics command. The distance between the drainage network and the fragments was evaluated with the Generate Near Table command. All spatial analyses were performed using ArcGis 10.3 software.

\section{Spectral evaluation of forest fragments}

For the spectral evaluation of vegetation quality, the Normalized Difference Vegetation Index (NDVI) was applied as proposed by Rouse et al. (1974):

$$
N D V I=\frac{N I R+R E D}{N I R-R E D}
$$

where: RED is the sensor band in the red range; and NIR is the sensor band in the near infrared range.

The NDVI results in an index image with a range from -1 to +1 . A healthy vegetation corresponds to values around 0.2 and 0.8 , but only the scores equal to or greater than 0.5 represent forest vegetation with biomass concentration (ROUSE et al., 1974; MEI et al., 2015). The photochemical reflectance of the fragments was mapped based on the Photochemical Reflectance Index (PRI), identifying the areas of highest photosynthetic efficiency through the relationship between the absorption feature in the blue electromagnetic spectrum and the peak reflectance of the vegetation in the green electromagnetic spectrum, as proposed by Gamon (1992):

$$
P R I=\frac{B L U E+G R E E N}{B L U E-G R E E N}
$$


where: PRI is the photochemical reflectance index; BLUE is the sensor band in the blue range; and GREEN is the sensor band in the green range.

The PRI values were rescaled to positive values seeking to normalize the range at 0 and 1 , generating the Photochemical Reflectance Index rescaled to positive values (sPRI), according to the equation below:

$$
s P R I=\frac{P R I+1}{2}
$$

Carbon flux was calculated by crossing the NDVI and sPRI indices, generating the $\mathrm{CO}_{2}$ Flux (Carbon Flux) index, according to the equation proposed by Rahman et al. (2000):

$$
\text { CO2Flux }=\text { NDVI } * \text { sPRI }
$$

\section{RESULTS}

Montana Dense Ombrophilous Forest fragments were quantified in 197 fragments and account for 37\% of the territorial area of the Una river basin. Studies on forest area fragments in river basins have shown values similar to those of the present study. Table 2 shows the metrics for classes and fragments, while Figure 2 shows the size of the fragments. The spot size was estimated at 3,589 ha, average size of 17 ha, 905 meters of edges, and average density of $266 \mathrm{~m} / \mathrm{ha}$. Most fragments (53\% of the total) are smaller than 5 ha, while medium fragments account for $40 \%$ and large fragments account for $7 \%$ of the total. The relationship between fragments and physical relief characteristics are presented in Figure 3.

Table 2. Metrics of forest fragments

\begin{tabular}{|c|c|c|c|c|c|c|}
\hline LEVEL & GROUP & METRICS & \multicolumn{4}{|c|}{ RESULT } \\
\hline \multirow{6}{*}{ Class } & \multirow{2}{*}{ Area } & Class area & \multicolumn{4}{|c|}{3.589 ha } \\
\hline & & Number of fragments & \multicolumn{4}{|c|}{197 fragments } \\
\hline & \multirow{2}{*}{ Size } & Average spot size & \multicolumn{4}{|c|}{17 ha } \\
\hline & & Standard deviation of the spot size & \multicolumn{4}{|c|}{3.786} \\
\hline & \multirow{2}{*}{ Edge } & Edge density & \multicolumn{4}{|c|}{$266 \mathrm{~m} / \mathrm{ha}$} \\
\hline & & Total edges & \multicolumn{4}{|c|}{$905 \mathrm{~m}$} \\
\hline & & & Min. & Mean & Max. & SD \\
\hline & \multirow{4}{*}{ Area } & Fragment area & $1 \mathrm{ha}$ & 17 ha & 306 ha & 37.96 \\
\hline & & Fragment perimeter & $550 \mathrm{~m}$ & $4594 \mathrm{~m}$ & $63270 \mathrm{~m}$ & 80085.78 \\
\hline \multirow[t]{3}{*}{ Fragment } & & Perimeter/area ratio & 0.01 & 0.04 & 0.12 & 0.01 \\
\hline & & Fractal dimension & 1.30 & 1.41 & 1.55 & 0.04 \\
\hline & Shape & Shape index & 1.36 & 3.04 & 11.50 & 1.49 \\
\hline
\end{tabular}

Tabela 1. Métricas dos fragmentos florestais 

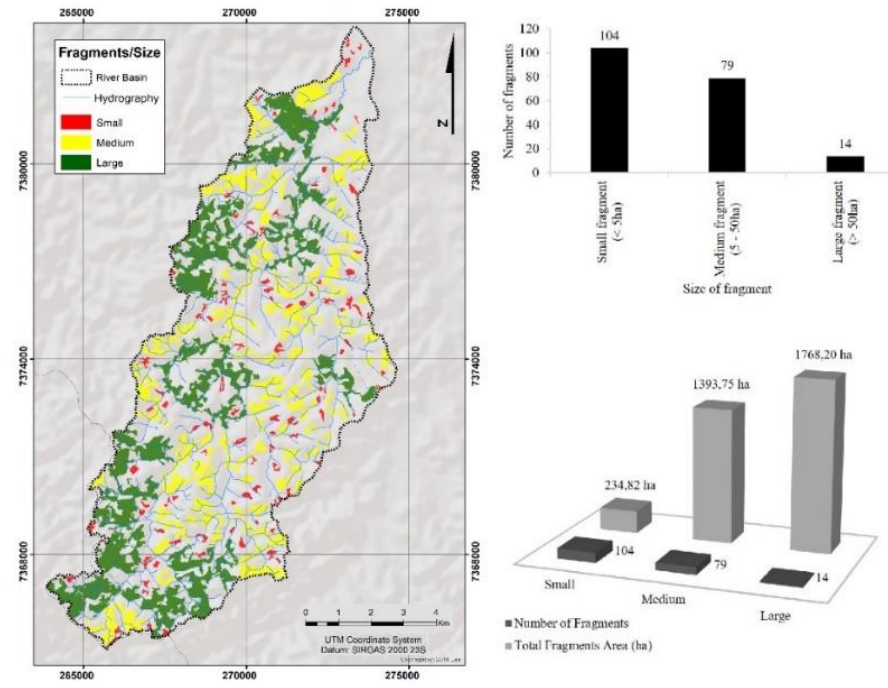

Figure 2. Relationship between the number of forest fragments and their respective areas. Figura 2. Relação entre o número de fragmentos florestais e as suas respectivas áreas.
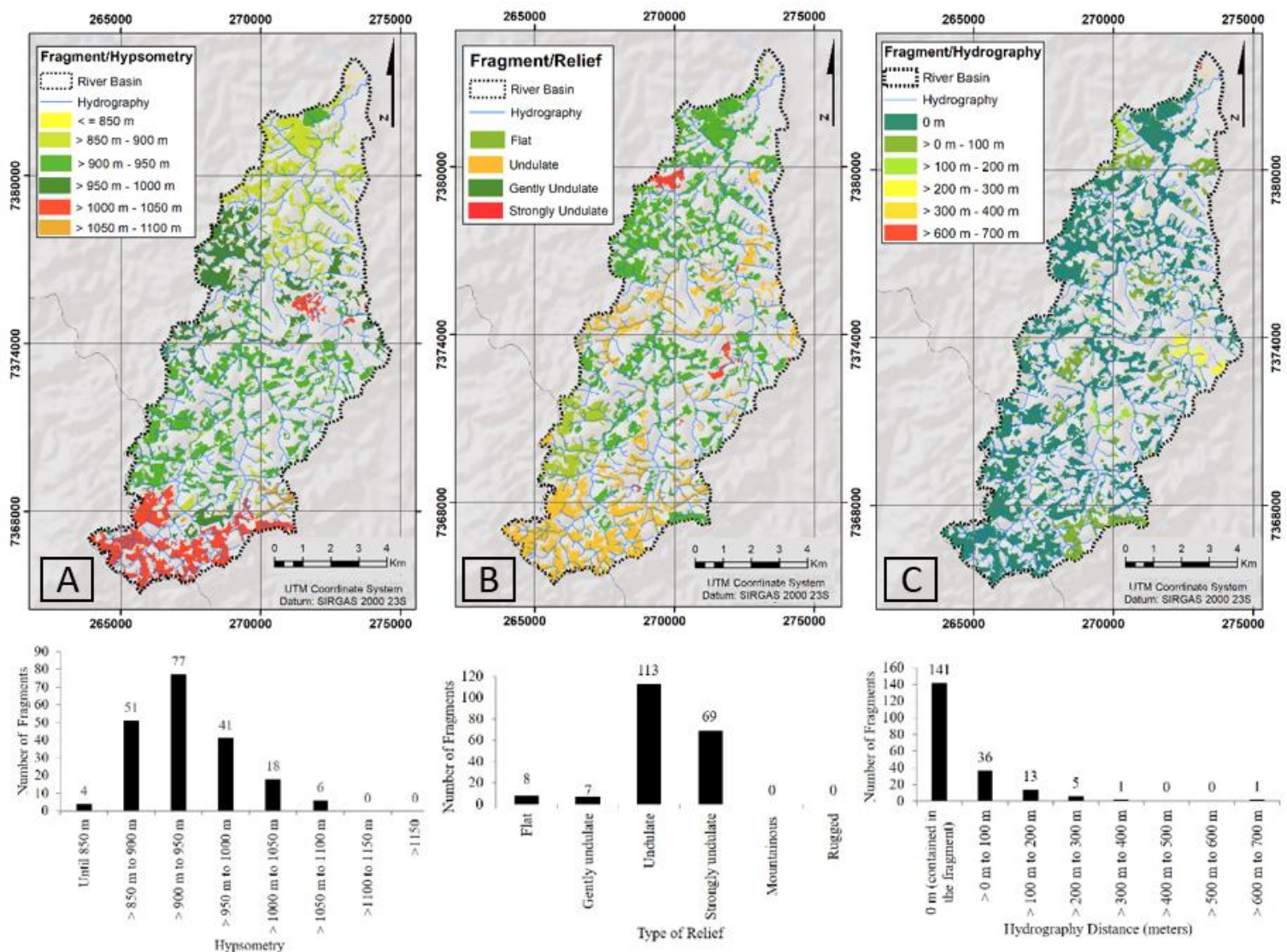

Figure 3. Association of forest fragments with hypsometric, relief, and hydrographic means.

Figura 3. Associação dos fragmentos florestais com a média hipsométrica, de relevo e hidrografia.

Most fragments were located at an average altitude of 850 to $950 \mathrm{~m}$ (Figure 3A). Regarding the slope, the fragments are in undulating and strongly undulating areas, with difficulty of access and presence of slope allowing these areas to be intact and conserved (Figure 3B). The analysis of fragments and drainage networks identified 141 fragments with some drainage inside (Figure 3C). Among the remaining fragments, 13 are distanced $200 \mathrm{~m}$ 
apart from the drainage, while another 6 are distanced from $300 \mathrm{~m}$ to $700 \mathrm{~m}$ apart. The most distant fragments are located close to the river basin exutory, which may also reflect the incident edge effect, since the surrounding of these fragments correspond to urban areas and areas used for temporary cultivation and pasture.

As for spectral photosynthetic characteristics, Figure 4 shows the spectral behavior of forest areas. The fragments presented NDVI values in the range [0.50 - 0.80], averaging 0.62, (Figure 4A). As for photosynthetic production, a moderate production capacity was observed during the evaluated period. The sPRI varied in the range [0.47 - 0.60], averaging 0.50 (Figure 4B). The $\mathrm{CO}_{2}$ flux reveals a low carbon flux absorbed by forest vegetation, ranging between [0.20 - 0.42] and averaging 0.31 . Regarding atmospheric carbon, the better the use of radiation and the greater the photosynthesis, the greater the possibility of the plant capturing atmospheric carbon in its photosynthetic processes (Figure 4C).
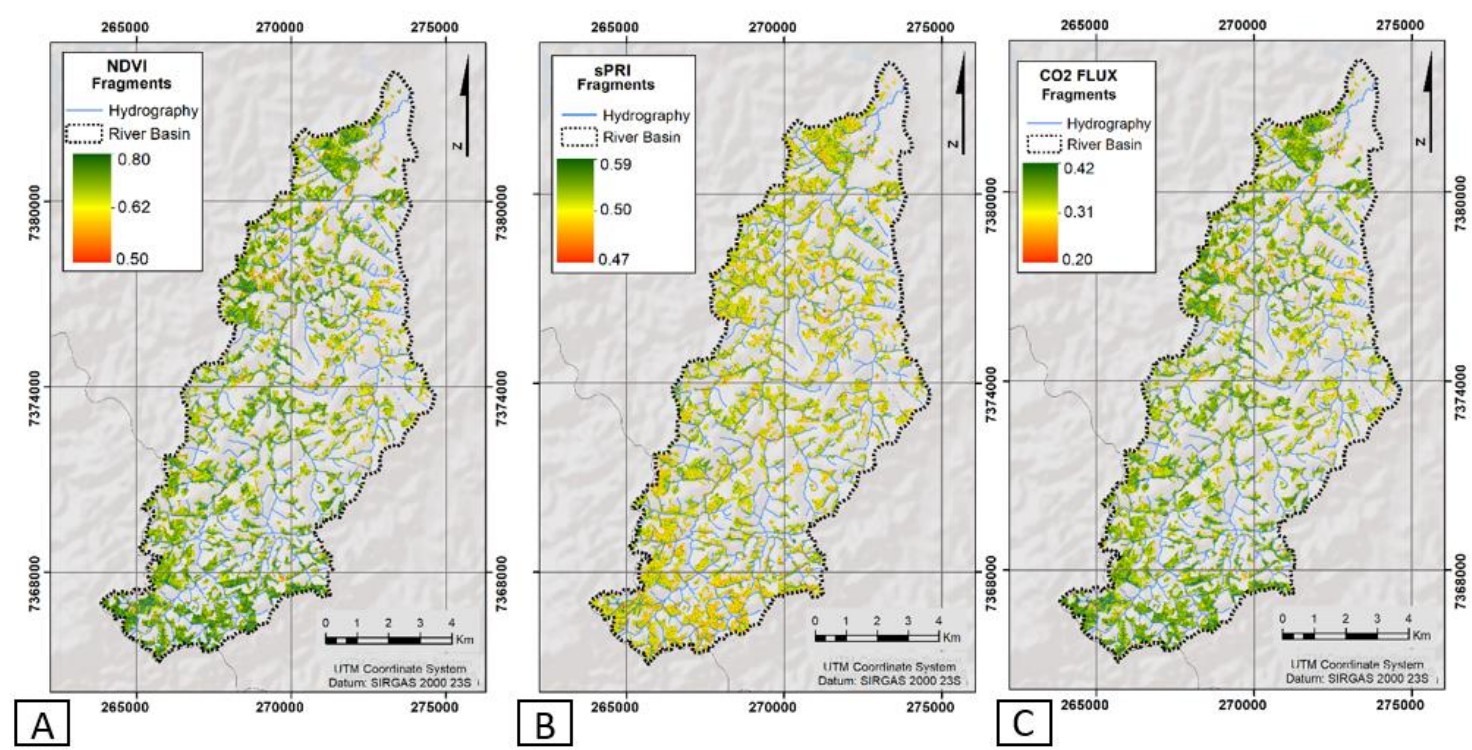

Figure 4. NDVI, sPRI and $\mathrm{CO}_{2}$ Flux of the forest fragments.

Figura 4. NDVI, sPRI e $\mathrm{CO}_{2}$ Flux dos fragmentos florestais.

\section{DISCUSSION}

In Chile, Bizama et al. (2011) noted that only $45 \%$ of the fragments covered the Aysén river basin. These fragmentation rates can be explained by the type of land use, which allows agricultural and urban uses, becoming a barrier to the flow of fauna and flora and to the maintenance of local biodiversity in these ecosystems. The greater the economic vocation of the area, the higher the rate of deforestation for new productive areas (BIZAMA et al., 2011; GOERL et al., 2011).

The size of the spots is intertwined with many ecosystem processes that require a minimum of contiguous preserved area to occur. The opposite configures the edge effect, being so called because of the action of external factors that affect the fragments and predispose the ecological system to damage (WULDER et al., 2009).

The occurrence of large amounts of small forest fragments has been common in Atlantic Forest landscapes and also recorded in river basin areas, indicating that 40 to $50 \%$ of the territories are comprised by small fragments of vegetation due to economic growth, livestock expansion, logging, and introduction of exotic species (CALEGARI et al., 2010; BIZAMA et al., 2011; PIROVANI et al., 2014).

The Una river river basin is predominantly agricultural, what justifies its influence on local fragmentation. The situation was similar in the Poxim river river basin in Sergipe State and in the Santa Alice river basin in southern Brazil, with these predominantly agricultural river basins having the highest percentages of small forest fragments due to plot planting and the construction of roads for production flow (GOERL et al., 2011; JESUS et al., 2015).

The inverse relationship between fragment sizes was also observed in the studies by Almeida and Moro (2007) and Pirovani et al. (2014), who identified a greater predominance of Atlantic Forest remnants with a high number of small fragments, but with a low total area in their summation in the river basins and parks evaluated. For Pirovani et al. (2014), the larger the perimeter/area ratio of the fragment, the greater the edge effect and the

FLORESTA, Curitiba, PR, v. 50, n. 1, p. 1053 - 1062, jan/mar 2020.

Lopes, E. R. N. et.al.

ISSN eletrônico 1982-4688 
irregularity of its shape, predisposing it to external factors and anthropogenic disturbances that affect the ecological community as a whole.

Although no fragments were found in mountainous and steep reliefs, the three largest fragments of the present study were located south of the river basin, also concentrating the areas with the highest altitudes. In contrast, areas with easy access and lack of slope have the lowest fragmentation rates, reflecting the high incidence of urban occupation and agricultural activities that tend to suppress natural areas, as observed in the northern portion, where the prevalence of flat relief is common.

Regarding the spectral analysis of forest fragments, the vegetation indices generated by RS are important indicators of plant environmental quality, helping to understand the behavior of canopy reflectance and water status in leaf structures. In this sense, these indices become very useful tools for environmental studies (AHAMED et al., 2011; DEMARCHI et al., 2011).

This investigation is made possible by the red wavelengths that are absorbed by chloroplasts, while the near infrared wavelength is reflected during the incidence of sunlight on vegetation. As the spectrum is unique to vegetation, if near infrared reflectance is much higher than red reflectance, a considerable amount of vegetation can be considered to exist (JOHANSEN; TOMMERVIK, 2014).

The NDVI was evaluated during the wet season in the region, where the rainfall average correspond to $129 \mathrm{~mm}$ in November according to the time series provided by the São Paulo Integrated Center for Agrometeorological Information, inferring that there may be an influence of rainfall on active plant biomass (CIIAGRO, 2015). In the study by Ávila et al. (2014), the fragments of dense ombrophilous forest of the Ribeirão Lavrinha river basin also presented high NDVI scores when associated with the wet season.

In the river basin, initial values of increased rainfall are already sufficient for the vegetation to reach the score of 0.80 , considered an excellent value by Rouse et al. (1974). The farther from the interior of the river basin, the higher the quality of plant biomass, as can be observed in the far west and far south in water dividers, where fragments with the highest vegetative biomass scores predominate. This fact suggests that altitude and slope influence vegetation conservation and corroborate the relationship between fragmentation and physical characteristics of the terrain.

The highest SPRI values were also found for the fragments in the river basin boundaries, associated with water body margins and with the highest NDVI scores. The observed photosynthetic regularity may be justified by the higher sPRI values when associated with higher rainfall; with water reduction, the use of xanthophyll pigments in photosynthetic efficiency will be altered in the vegetation (GAMON et al., 1992; CANAVESI et al., 2010).

Although fragments have shown an active biomass, the photosynthetic process may be influenced by the still reduced rainfall due to the beginning of the humid period, with higher scores in December and January, averaging $188.50 \mathrm{~mm}$ and $241.90 \mathrm{~mm}$, respectively.

The assessments allow us to indicate measures to minimize fragmentation of the Atlantic Forest in the Una river river basin. The consequences of forest fragmentation consist of changes in air humidity, temperature, solar radiation, erosion, siltation and reduction of watercourses, besides greater evapotranspiration, loss of genetic and soil microbiological biodiversity, loss of flora and fauna, reduced density, abundance, and alteration of vegetation structure.

Measures for the conservation of fragments are thus required, seeking to stimulate discussions for the revegetation of exposed and degraded areas, and the increase and interconnection of fragments in the river basin. Moreover, it is necessary to evaluate the structure of the fragments, the irregular shape, and the incident edge effect, suggesting a greater control of activities that induce plant suppression and accelerate fragmentation, since $60 \%$ of the river basin is occupied by anthropic activities. Fragments to the west and at low altitudes show a reduction trend and lack the ability to protect biological diversity, with the occurrence of inbreeding, extinction of species, and populations in small numbers (PIROVANI et al., 2014).

Maintaining the development and density of the fragments is essential to the increased carbon flux. Thus, stimulating the conservation of dense fragments, at higher altitudes and in sloping areas, appears to be effective to contribute to the reduction of atmospheric carbon. In addition, encouraging the formation of ecological corridors and the reforestation of native species, forming a protective band in the immediate surroundings of the fragments, can contribute to increased protection, reducing the invasion of exotic species and the occurrence of burns (MUCHAILH et al., 2010).

Furthermore, as the river basin houses a considerable area of the urban area of Ibiúna city, environmental actions must be carried out by the government to conserve fragments around urban centers. Associated with this, action of the river basin committee is necessary to involve the local community in environmental education activities that encourage the practice of conservation actions in sites with high agricultural production. 


\section{CONCLUSIONS}

The analyses carried out allow us to conclude that:

- The Una river basin has a high forest fragmentation identified by shape index, perimeter/area ratio, and fractal dimension, being related to local agricultural vocation and the growth of productive areas.

- Despite the low percentage of fragments over 50 hectares, the river basin has relevant areas that deserve to be conserved, highlighting those located at higher altitudes, slopes, and comprising watercourses.

- The vegetative vigor, photochemical efficiency, and atmospheric carbon flux of the fragments were associated with the drainage contained therein and with higher altitudes and slopes, so forest fragments are more conserved and photosynthetically active at these sites.

- The government and civil organizations must develop environmental education activities and research on the physical environment, besides establishing ecological corridors, aiming at local awareness and conservation of the vegetation areas of the river basin.

\section{ACKNOWLEDGEMENTS}

This study was carried out with the support of the São Paulo Institute of Technological Research (FIPT) to the first author, while the second author had the support of the Higher Education Personnel Improvement Coordination - Brazil (CAPES) - Financing Code 001. Case Number: 88882.434503/2019-01.

\section{REFERENCES}

AHAMED, T.; TIAN, L.; ZHANG, Y.; TING, K. C. A review of remote sensing methods for biomass feedstock production. Biomass and Bioenergy, New York, v. 35, p. 2455-2469, 2011.

ALMEIDA, C. G.; MORO, R. S. Análise da cobertura florestal no Parque Nacional dos Campos Gerais, Paraná, como subsídio ao seu plano de manejo. Terr@ Plural, Ponta Grossa, v. 1, n. 1, p.115-122, 2007.

BIZAMA, G.; TORREJON, F.; AGUAYO, M.; MUNÕZ, M. D.; ECHEVERRIA, C.; URRUTIA, R. Pérdida y fragmentación del bosque nativo en la cuenca del río Aysén (Patagonia-Chile) durante el siglo XX1. Revista de Geografía Norte Grande, Santiago, v. 49, p. 125-138, 2011.

CALEGARI, L.; MARTINS, S. V.; GLERIANI, J. M.; SILVA, L.; BUSATO, L. C. Analysis of the dynamics of forest fragments in the city of Carandaí, MG, for forest restoration. Revista Árvore, Viçosa, v. 34, n. 5, p. 871$880,2010$.

CANAVESI, V.; PONZONI, F. J.; VALERIANO, M. M. Estimativa de Volume de madeira em plantios de Eucalyptus spp. utilizando dados hiperespectrais e dados topográficos. Revista Árvore, Viçosa, v. 34, n. 3, p. 539549, 2010.

CHOAT, B. Global convergence in the vulnerability of forests to drought. Nature, New York, v. 491, p. 752-755, 2012.

CIIAGRO. CENTRO INTEGRADO DE INFORMAÇÕES AGROMETEREOLÓGICAS. Série histórica de pluviosidade mensal de Sorocaba - SP. Disponível em: <http://www.ciiagro.sp.gov.br/ciiagroonline/Quadros/QChuvaPeriodo.asp> Acesso em: 21 jun. 2015.

DEMARCHI, J. C.; PIROLI, E. L.; ZIMBACK, C. R. L. Análise temporal do uso do solo e comparação entre os índices de vegetação NDVI e SAVI no município de Santa Cruz do Rio Pardo - SP usando imagens Landsat-5. Raega, Curitiba, v. 21, p. 234-271, 2011.

EMBRAPA. Centro Nacional de Pesquisa de Solos (Rio de Janeiro, RJ). Sistema brasileiro de classificação de solos. 2. ed. - Rio de Janeiro: EMBRAPA-SPI, 2006. 306 p.

FORESTRY COMMISSION. Woodland area, planting and restocking. 2012. Disponível em: <http://www.forestry.gov.uk/pdf/WAPR2015.pdf/\$FILE/WAPR2015.pdf > Acesso em 11 mai 2016.

GAMON, J. A.; PENUELAS, J.; FIELD, C. B. A narrow waveband spectral index that tracks diurnal changes in photosynthetic efficiency. Remote Sensing of Environment, New York, v. 41, p. 35-44, 1992.

FLORESTA, Curitiba, PR, v. 50, n. 1, p. 1053 - 1062, jan/mar 2020

Lopes, E. R. N. et.al.

ISSN eletrônico 1982-4688 
GOERL, R. F.; SIEFERT, A. C.; SCHULTZ, G. B.; SANTOS, C. S.; SANTOS, I. Elaboração e Aplicação de Índices de Fragmentação e Conectividade da Paisagem para Análise de Bacias Hidrográficas. Revista Brasileira de Geografia Física, Recife, v. 5, p. 1000-1012, 2011.

JAMALI, S.; SEAQUIST, J.; EKLUNDH, L.; ARDO, J. Automated mapping of vegetation trends with polynomials using NDVI imagery over the Sahel. Remote Sensing of Environment, New York, v. 141, p. 7989, 2014.

JESUS, E. N.; FERREIRA, R. A.; ARAGAO, A. G.; SANTOS, T. I. S.; ROCHA, S. L. Estrutura dos fragmentos florestais da bacia hidrográfica do rio Poxim-SE, como subsídio à restauração ecológica. Revista Árvore, Viçosa, v. 39, n. 3, p. 467-474, 2015.

JOHANSEN, B.; TOMMERVIK, H. The relationship between phytomass, NDVI and vegetation communities on Svalbard. International Journal of Applied Earth Observation and Geoinformation, New York, v. 27, p. 20 30, 2014.

KENNEL, E.; HUBBART, J. A.; IKEM, A. A comparison of forest and agricultural shallow groundwater chemical status a century after land use change. Science of the Total Environment, New York, v. 529, p. 82-90, 2015.

LOURENÇO, R. W.; CUNHA E SILVA, D. C.; SALES, D. C. Elaboração de uma metodologia de avaliação de fragmentos de remanescentes florestais como ferramenta de gestão e planejamento ambiental. Ambiência, Guarapuava, v. 10, n. 3 p. $685-698,2014$.

MCGARIGAL, K. FRAGSTATS: Spatial pattern analysis program for categorical maps: user manual. 182p. 2015.

MCT. MINISTÉRIO DA CIÊNCIA E TECNOLOGIA. Atlas dos Remanescentes Florestais da Mata Atlântica: Período de 2013-2014. FUNDAÇÃO SOS MATA ATLÂNTICA E INSTITUTO NACIONAL DE PESQUISAS ESPACIAIS. São Paulo, 2015. 60p.

MEI, A.; MANZO, C.; FONTINOVO, G.; BASSANI, C.; ALEGRINI, A.; PETRASCCHINI, F. Assessment of land cover changes in Lampedusa Island (Italy) using Landsat TM and OLI data. Journal of African Earth Sciences, Cape Town, v. 12, p. 15-24, 2015.

MUCHAILH, M. C.; RODERJAN, C. V.; CAMPOS, J. B.; MACHADO, A. L. T.; CURCIO, G. R. Metodologia de planejamento de paisagens fragmentadas visando a formação de corredores ecológicos. Revista Floresta, Curitiba, v. 40, n. 1, p. 147-162, 2010.

PIROVANI, D. B.; SILVA, A. G.; SANTOS, A. R.; CECILIO, R. A.; GLERIANI, J. M.; MARTINS, S. V. Análise espacial de fragmentos florestais na bacia do rio Itapemirim, ES. Revista Árvore, Viçosa, v. 38, n. 2, p. 271-281, 2014.

RAHMAN, A. F. et al. Modeling CO2 flux of boreal forests using narrow-band indices from AVIRIS imagery. In: AVIRIS Workshop. Proceedings... JPL/NASA, Pasadena, California, 2000.

ROUSE, J. W.; HAAS, R. H.; SCHELL, J. A.; DEERING, D. W. Monitoring vegetation systems in the great plains with ERTS. In: FRADEN, S. C.; MARCANTI, E. P.; BECKER, M. A. Earth Resources Technology Satellite- 1 Symposium. Washington: NASA, 1974. 309-317p.

TUNDISI, J. G. Novas perspectivas para a gestão dos recursos hídricos. Revista USP, São Paulo, n. 70, p. 24-35, 2006. 